\title{
Dynamics of transparent exopolymeric particles (TEP) and particle-associated carbohydrates in the Dona Paula bay, west coast of India
}

\author{
P V BHASKAR ${ }^{1,2, *}$ and NARAYAN B BhOSLE ${ }^{1}$ \\ ${ }^{1}$ Marine Corrosion and Materials Research Division, National Institute of Oceanography, \\ Dona Paula, Goa 403004 , India. \\ 2 Present address: Chemical Oceanography Division, National Institute of Oceanography, \\ Dona Paula, Goa 403 004, India. \\ *e-mail: pbhaskar23@yahoo.com
}

Surface seawater samples were collected over a period of 27 months at a shallow water station in Dona Paula bay from 1998-2000. The samples were analyzed to assess the seasonal variations, inter-annual variability and the contributions of:

- transparent exopolymeric particles (TEP) concentration,

- two forms of particle-associated carbohydrates - $1.5 \mathrm{M} \mathrm{NaCl} /$ saline extracted (Sal-PCHO) and $10 \mathrm{mM}$ EDTA-extracted (CPCHO) and

- total bacterial abundance (TBA) to particulate organic carbon pool.

A distinct inter-annual variability was observed with an increase in the bacterial abundance, chlorophyll $a(\mathrm{Chl} a)$, TEP and Sal-PCHO and their greater contribution to particulate organic carbon during May 1998-1999 than in June 1999-July 2000. Overall, there was no statistically significant correlation of TEP with phytoplankton biomass (Chl a), Sal-PCHO, CPCHO and hydrodynamic conditions. A weak inverse correlation was observed between TEP and TBA $(r=-0.397 ; p<0.05)$ but the role of TEP as a C-source for bacteria was not evident. Both Sal-PCHO and CPCHO appeared to be two distinct forms of carbohydrates. Unlike CPCHO, Sal-PCHO concentrations showed a positive trend with $\mathrm{Chl} a$ and significant linear correlation with bacterial abundance $(r=0.44, p<0.007, n=48)$, indicating that Sal-PCHO as carbon source might have supported bacterioplankton abundance. The mean \% TEP-C contribution to the annual average organic carbon for 1998-2000 was $6.9 \% \pm 5.8 \%$, next only to phytoplankton-C $(33.1 \pm 22.1 \%)$ and greater than bacterial-C $(4.6 \% \pm 4.6 \%)$ or carbohydrate-C $(<3.8 \%)$. Despite its greater contribution to the organic carbon pool, the contribution of TEP-C to the benthic carbon demand and its fate in the study area could not be ascertained in this study.

\section{Introduction}

In the marine environment, carbohydrates are one of the most common forms of organic carbon that exist as both dissolved and particulate/particleassociated forms (Romankevich 1984). Carbohydrates also form an important constituent of mucus exudates, extracellular polymers and cell envelopes, which are produced during the growth of phytoplankton and bacteria (Myklestad et al 1989; Decho 1990; Kaltenböck and Herndl 1992), and contribute to the bulk carbohydrate in surrounding waters (Pakulski and Benner 1994; Bhosle et al 1998). Since exudates and/or extracellular

Keywords. Transparent exopolymeric particles; particle-associated carbohydrates; bacteria; phytoplankton. 
polymers are highly sticky in nature (Alldredge et al 1993; Passow et al 1994), they bind suspended particulate matter and are considered vital for the formation of aggregates (Engel 2004). Microbial exudates and cell envelopes remain attached to the cell-wall either as tight capsules (extracted by EDTA and referred hereafter as CPCHO) or as loosely attached slimes (extracted by $1.5 \mathrm{M} \mathrm{NaCl}$ and referred hereafter as Sal-PCHO) (Bhosle et al 1995; Underwood et al 1995). These capsular/slime EPS form an important constituent of particulate organic matter (Decho 1990). Both are found abundantly in biofilms, benthic microbial mats, cell aggregates, marine snow, etc. (Decho 1990, 2000; Herndl 1995; Goto et al 1999), help in protection, sequestering nutrients, cell aggregation, sedimentation and create a microenvironment for microorganisms (Bhaskar and Bhosle 2004 and the references therein).

Dissolved polysaccharides may coagulate spontaneously to form gel-like particles (Chin et al 1998). Transparent exopolymer particles (TEPs) are one such class of particles found ubiquitously distributed in the marine environment, rich in acidic polysaccharides and have high C:N ratios. They are generally abundant $\left(10^{3}\right.$ to $\left.10^{6} \mathrm{ml}^{-1}\right)$ in both open oceans and coastal waters with sizes ranging from $<1 \mu \mathrm{m}$ to $200 \mu \mathrm{m}$ (Alldredge et al 1993; Schuster and Herndl 1995; Mari and Burd 1998). Recently, it has been suggested that the exudates of marine phytoplankton and bacteria (Passow 2002 and the references therein), macroalgae (Ramaiah et al 2000; Thornton 2004), marine invertebrates (McKee et al 2000) and benthic biofilms (Decho 2000) are some of the important sources for the production of TEP. Since both TEP and particleassociated carbohydrates have similar sources and are a rich source of organic carbon, their distribution and biogeochemical transformations in a coastal environment are important to understand their role in sustaining the carbon demand in the near-shore waters.

Of late, there has been a growing interest in the relationship between TEP and the particleassociated carbohydrates (Passow and Alldredge 1995a; Mari and Kiørboe 1996), their distribution and influence on bacterial activity (Passow and Alldredge 1994; Dam and Drapeau 1995), coagulative properties (Mari and Burd 1998) and their role in the biogeochemical processes in the marine environment (Kumar et al 1998; Passow et al 2001; Passow 2002). Most of the studies carried out on TEP are representative of the open ocean conditions wherein the major source of TEP is primary producers. On the contrary, there are very few reports from coastal environments. Most of the reports on the dynamics of TEP in near-shore waters are from temperate waters (Kiørboe et al

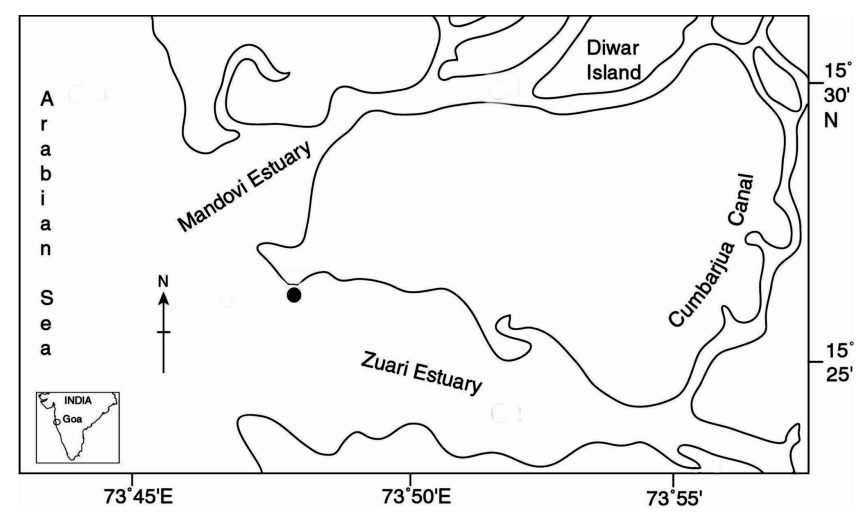

Figure 1. Map showing location of study area and sampling station.

1994; Schuster and Herndl 1995; Hung et al 2001; Engel et al 2002). The few reports on the distribution of TEP in tropical waters are based on one-time measurements in the oceanic waters of the Bay of Bengal and Arabian Sea (Kumar et al 1998; Ramaiah et al 2000). However, to the best of our knowledge, there are no reports on the seasonal distribution of TEP and particle-associated carbohydrates and its contribution to the particulate organic carbon pool in a tropical shallow water coastal environment.

In this paper, a seasonal data collected over a period of 27 months from May 1998-July 2000 (fortnightly from May 1998-June 1999 and monthly from July 1999-2000) is discussed to answer the following questions:

- Do TEP, Sal-PCHO and CPCHO have a similar seasonal and inter-annual variations at a shallow water tropical station?

- What is the contribution of these macromolecules to the particulate organic carbon pool at the station?

- Do TEP and particle-associated carbohydrates influence the bacterial abundance in these waters?

\subsection{Study area}

A 27-month field observation was carried out in the Dona Paula bay $\left(15^{\circ} 27^{\prime} \mathrm{N} ; 73^{\circ} 48^{\prime} \mathrm{E}\right)$ where the average depth was $3 \mathrm{~m}$ (figure 1). The sampling site experiences 3 seasons: monsoon (JuneSeptember), post-monsoon (October-January) and pre-monsoon (February-May). The details of the hydrodynamic conditions, chemistry, primary productivity and terrestrial inputs at the sampling station have been discussed elsewhere (Bhaskar et al 2000). Briefly, the study site is near the mouth of the Zuari river and the watercolumn characteristics are influenced by strong off-shore winds and tidal currents throughout the 
year. Tidal currents are strongest during the premonsoon months $\left(\sim 25 \mathrm{~cm} \mathrm{~s}^{-1}\right)$ (Bhaskar et al 2000) whereas wave induced turbulence is maximal in the monsoon months (Jayakumar, personal communication). Earlier studies indicate that the average sea-surface temperature and salinity varies from $25^{\circ} \mathrm{C}-35^{\circ} \mathrm{C}$ and $10-35 \mathrm{psu}$, respectively and nutrient (nitrate) concentrations are influenced by upwelling and freshwater inflow in the monsoon months (June to September) (Devassy and Goes 1988). The sediment resuspension in the study area is largely due to increased influx of land runoff and riverine inputs during monsoon and strong tidal currents during other seasons. Diatoms are the major primary producers in these waters and species of Navicula, Nitzchia, Skeletonema, Pleurosigma, Chaetoceros, Coscinodiscus and Rhizosolenia are abundantly found both in the water column (Devassy and Goes 1988) and consequently in sinking aggregates (Garg and Bhaskar 2000).

\section{Methods}

\subsection{Sampling}

Seawater samples were collected from $1 \mathrm{~m}$ below the surface during high tide at regular intervals during 1998-2000 using a 51 Niskin water sampler. The samples were processed for the analyses of temperature, salinity, nutrients, dissolved oxygen, various suspended particulate parameters and bacterial abundance.

\subsection{Sample analyses}

\subsubsection{Wind speed, hydrography and nutrients}

Surface wind speed data were obtained from the local meteorological station. Sea surface temperature was recorded immediately using a thermometer. Seawater samples collected as above were brought to the laboratory within half an hour of collection and analyzed for salinity and dissolved nitrate. Salinity was estimated following the silver nitrate titration method (Strickland and Parsons 1975). The dissolved nitrate was estimated spectrophotometrically following Parsons et al (1984).

\subsubsection{Particulate matter}

Aliquots of seawater samples for suspended particulate matter (SPM), particulate organic carbon (POC) and nitrogen (PON), chlorophyll $a(\mathrm{Chl} a)$, TEP and the two forms of particle-associated carbohydrates (Sal-PCHO and CPCHO) were filtered through pre-ashed $\left(450^{\circ} \mathrm{C}, 4 \mathrm{~h}\right) \mathrm{GF} / \mathrm{F}$ Whatman filters. The filters of SPM, POC, PON and particle-associated carbohydrates were oven-dried at $<50^{\circ} \mathrm{C}$ prior to analyses. All the samples were analyzed in duplicates.

The SPM samples were collected onto preweighed GF/F filter papers, rinsed with distilled water, oven-dried and weighed on a microbalance (model Mettler Toledo-AT 20). POC analysis was carried out following the dichromate oxidation method (Parsons et al 1984). PON was estimated following the semi-automatic wet-oxidation method (Raimbault and Gerd 1991).

The chlorophyll samples were extracted overnight in a known volume of $90 \%$ acetone at $4^{\circ} \mathrm{C}$, centrifuged at $5000 \mathrm{rpm}$ and the supernatant was measured for its fluorescence at $430 \mathrm{~nm}$ excitation and $670 \mathrm{~nm}$ emission wavelengths using a fluorescence spectrophotometer (Hitachi model F-2000). Phytoplankton derived carbon (Phyto-C) was calculated using a $\mathrm{POC} / \mathrm{Chl} a$ ratio of 40 (Banse 1977).

Both forms of particle-associated carbohydrates (Sal-PCHO and CPCHO) were analyzed following Underwood et al (1995) and Bhosle et al (1995). Briefly, Sal-PCHO and CPCHO samples were extracted using $1.5 \mathrm{M} \mathrm{NaCl}$ and $10 \mathrm{mM}$ EDTA, respectively. The samples were vortex mixed for 15 minutes, centrifuged and the supernatant was used to estimate carbohydrates following Dubois et al (1956). Carbon content of Sal-PCHO and CPCHO were estimated using a factor of 0.4 .

Glucose was used as a standard for both POC and carbohydrate analyses. EDTA was used as a standard for PON estimation.

\subsubsection{TEP sampling and quantification}

Samples for TEP were collected and analyzed following Alldredge et al (1993) except that $0.22 \mu \mathrm{m}$ Nuclepore polycarbonate membrane filters were used instead of $0.45 \mu \mathrm{m}$ pore size. The volume of sample $(25$ to $50 \mathrm{ml})$ varied with turbidity and filtered under low vacuum ( $<10 \mathrm{mbar})$. The particulate matter retained on the filters were then stained with prefiltered $(0.22 \mu \mathrm{m}) 0.02 \%$ Alcian blue in $0.06 \%$ glacial acetic acid $(\mathrm{pH}=2.5)$ and filtered dry under low vacuum. Blanks were prepared by filtering equal volume of distilled water and stained as stated earlier to correct the interference of the stain particles in TEP estimates. Clogging and adsorption of stain on to filters were negligible.

Both the sample and blank filters stained with Alcian blue were soaked in $6 \mathrm{ml}$ of $80 \%$ sulfuric acid for $2 \mathrm{~h}$. The filters were shaken intermittently during this period. The samples were 
Table 1. Mean, SD and range of various parameters in the surface waters during 1998-2000 and the same for the period 1998-99 and 1999-2000 at a shallow water station off Dona Paula bay.

\begin{tabular}{|c|c|c|c|c|c|c|c|c|c|}
\hline \multirow[b]{2}{*}{ Parameters } & \multicolumn{3}{|c|}{$1998-2000$} & \multicolumn{3}{|c|}{ 1998-1999 } & \multicolumn{3}{|c|}{ 1999-2000 } \\
\hline & Mean & $\mathrm{SD}$ & Range & Mean & $\mathrm{SD}$ & Range & Mean & $\mathrm{SD}$ & Range \\
\hline Suspended load ${ }^{\Psi}$ & 16.0 & 9.0 & $3.4-44.9$ & 16.00 & 9.7 & $4.9-44.9$ & 16.0 & 8.6 & $3.4-31.7$ \\
\hline Chlorophyll $a^{\Phi}$ & 4.8 & 2.8 & $1.2-12.3$ & 5.6 & 3.5 & $1.4-12.3$ & 3.9 & 1.5 & $1.2-6.3$ \\
\hline $\operatorname{TEP}^{\Omega}$ & 57.1 & 35.0 & $1.3-149.1$ & 44.2 & 19.6 & $13.0-82.1$ & 70.0 & 42.5 & $1.3-149.1$ \\
\hline Sal-PCHO $^{\Phi}$ & 24.3 & 20.0 & $4.5-101.6$ & 33.4 & 23.9 & $8.0-101.6$ & 14.6 & 7.0 & $4.5-26.1$ \\
\hline $\mathrm{CPCHO}^{\Phi}$ & 64.6 & 40.2 & $26.2-210.3$ & 65.8 & 43.7 & $44.7-210.3$ & 63.2 & 37.7 & $26.5-151.4$ \\
\hline $\mathrm{TBA}^{\infty}$ & 2.6 & 2.42 & $0.6-10.2$ & 3.6 & 3.0 & $1.1-10.2$ & 1.6 & 0.9 & $0.6-3.5$ \\
\hline $\mathrm{C}: \mathrm{N}(\mathrm{w}: \mathrm{w})$ & 9.5 & 3.5 & $2.4-18.8$ & 9.3 & 3.4 & $7.4-18.8$ & 9.8 & 3.7 & $2.4-13.3$ \\
\hline Phyto-C (\%-POC) & 33.1 & 22.1 & $5.5-84.2$ & 34.7 & 25.6 & $7.8-84.2$ & 25.2 & 12.7 & $5.5-48.9$ \\
\hline TEP-C (\%-POC) & 6.9 & 5.8 & $0.1-22.8$ & 6.1 & 5.8 & $2.1-22.8$ & 7.9 & 6.1 & $0.1-21.7$ \\
\hline Sal-PCHO-C (\%-POC) & 1.6 & 1.2 & $0.4-4.8$ & 1.8 & 1.8 & $0.5-4.8$ & 0.9 & 0.4 & $0.3-1.7$ \\
\hline CPCHO-C (\%-POC) & 3.8 & 1.8 & $1.3-10$ & 4.0 & 3.2 & $2.0-10.0$ & 3.6 & 1.6 & $1.3-6.5$ \\
\hline Bac-C (\%-POC) & 4.6 & 4.6 & $0.5-18.1$ & 4.9 & 6.9 & $1.1-18.0$ & 2.8 & 2.4 & $0.5-8.5$ \\
\hline Wind speed ${ }^{\xi}$ & 2.6 & 0.8 & $1.8-4.8$ & 2.5 & 0.6 & $1.9-3.9$ & 2.6 & 1.0 & $1.8-4.8$ \\
\hline Temperature $^{\dagger}$ & 29.4 & 1.7 & $26.7-33.0$ & 29.8 & 1.7 & $26.7-32.0$ & 28.9 & 1.7 & $27.0-33.0$ \\
\hline Salinity & 30.8 & 5.8 & $14.7-39.7$ & 30.8 & 3.8 & $22.4-34.5$ & 30.8 & 7.7 & $14.7-39.7$ \\
\hline Nitrate* & 4.1 & 3.8 & $0.03-14.2$ & 3.9 & 3.6 & $0.4-11.6$ & 4.4 & 4.2 & $0.03-14.2$ \\
\hline
\end{tabular}

Note: ${ }^{\Psi}: \mathrm{g} \mathrm{m}^{-3} ;{ }^{\Phi}: \mathrm{mg} \mathrm{m}^{-3} ;{ }^{\Omega}: \mathrm{mg}$ Xanthan gum equivalent $\mathrm{m}^{-3} ;{ }^{\infty}: \times 10^{6}$ cells $\mathrm{ml}^{-1} ;{ }^{\xi}: \mathrm{m} \mathrm{s}^{-1} ;{ }^{\dagger}:{ }^{\circ} \mathrm{C} ;{ }^{*}: \mu \mathrm{M}$.

then centrifuged and the supernatant was measured spectrophotometrically at $787 \mathrm{~nm}$ (Passow and Alldredge 1995b). The TEP concentration was estimated using the following equation:

$$
\mathrm{TEP}=\left(E_{787}-B_{787}\right) \times F_{x} V_{f}^{-1}
$$

where $E_{787}$ is sample extinction, $B_{787}$ is blank extinction, $F_{x}$ is factor of calibration and $V_{f}$ is the volume filtered in litres. The factor $F_{x}$ was calculated from the equation

$$
F_{x}=M\left[\left(E_{787}-B_{787}\right) V_{s t}^{-1}\right]^{-1}
$$

where $M$ is the weight of the Xanthan gum standard used for calibration ( $\mathrm{mg} \mathrm{m}^{-3}$ Xanthan gum) and $V_{s t}$ is the volume of the standard filtered in litres. The coefficient of variance for the entire sampling was $35 \%$. The TEP concentrations are expressed as equivalence of Xanthan gum. Carbon content of TEP was estimated using a factor of 0.75 (Engel and Passow 2001).

\subsubsection{Total bacterial abundance (TBA)}

Seawater samples were collected in sterile plastic bottles, fixed with $4 \%$ formalin and stored under refrigeration. Total bacterial abundance was estimated following the direct acridine orange staining method (Parsons et al 1984). Briefly, 1-2 ml of the fixed samples was stained for $2 \mathrm{~min}$ in duplicates with 0.1 to $0.2 \mathrm{ml}$ of prefiltered $(0.22 \mu \mathrm{m})$ Acridine orange. The samples were then filtered onto
$0.22 \mu \mathrm{m}$ prestained black Nuclepore polycarbonate membrane filters. The filters were then placed on a glass slide having a drop of fluorescence free oil, another drop of oil placed over the filter paper and covered with a cover glass. The slide was then illuminated with a UV lamp and viewed at $1000 \times$ magnification using a blue filter. About 10 12 fields were counted per filter and the average field count was used to calculate the abundance for the volume of sample filtered. Similarly, the total Bact-C was estimated by assuming the bacterial cell carbon content as $11 \mathrm{fg} \mathrm{cell}^{-1}$ (Garrison et al 2000).

\subsection{Statistical analyses}

Suitable statistical analyses including correlation coefficient, principal component analyses and oneway ANOVA were carried out to evaluate the interrelationship between various parameters and their inter-annual variations during the sampling period. All the statistical analyses were carried out using Statistica software.

\section{Results}

\subsection{Wind speed, hydrography and nutrients}

The seasonal changes in the hydrography and nutrients at the sampling stations were influenced by strong south-west monsoonal winds (June August). The average wind speed, sea surface 

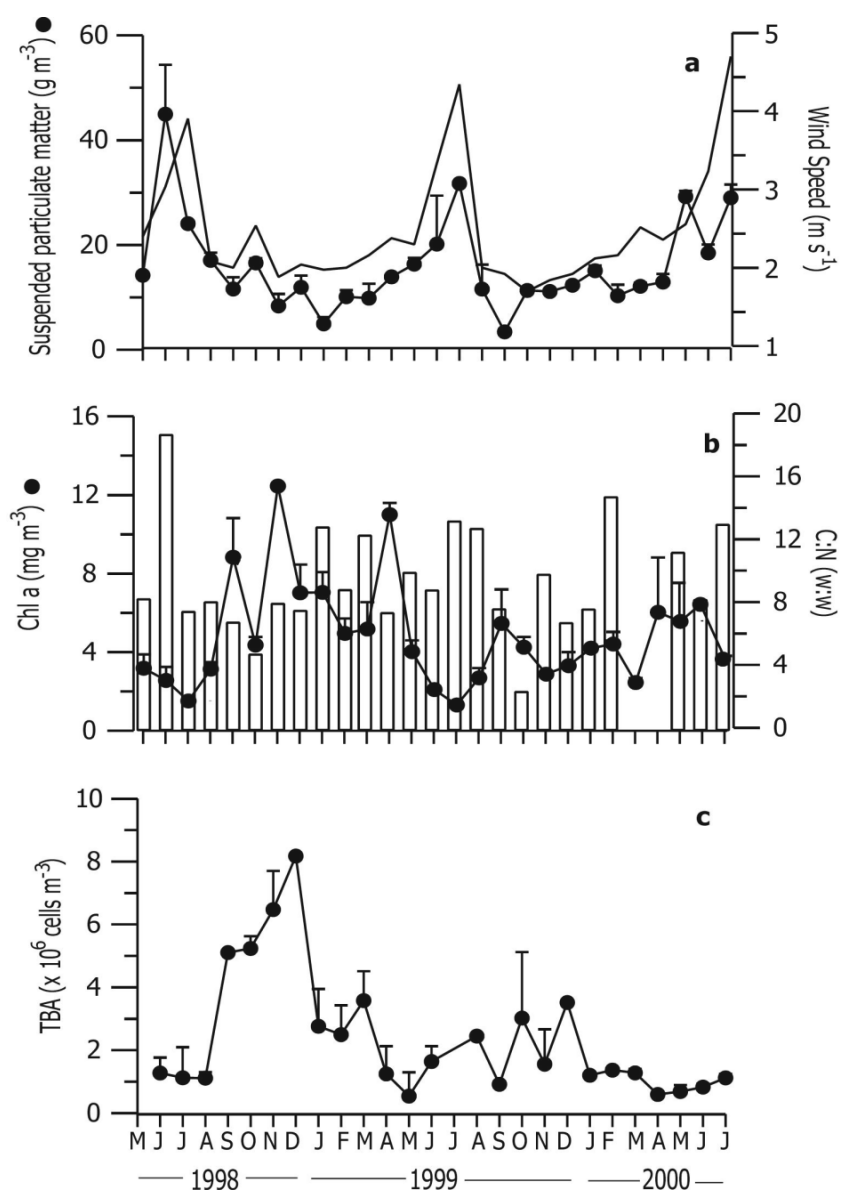

Figure 2. Seasonal distribution of (a) suspended particulate matter (SPM) and wind speed, (b) chlorophyll a and $\mathrm{C}: \mathrm{N}$ ratio and (c) total bacterial abundance (TBA) in the surface waters of Dona Paula bay during 1998-2000.

temperature, surface salinity and dissolved nitrate are shown in table 1 . The average monthly wind speed, surface temperature, salinity and dissolved nitrate for the entire sampling period ranged from $1.8 \mathrm{~m} \mathrm{~s}^{-1}$ (September 1999) to $4.8 \mathrm{~m} \mathrm{~s}^{-1}$ (July 2000), $26.7^{\circ} \mathrm{C}$ (July 2000) to $33^{\circ} \mathrm{C}$ (March 2000), $14.7 \mathrm{psu}$ (June 2000) to $39.7 \mathrm{psu}$ (March 2000), and $0.03 \mu \mathrm{M}$ (September 1999) to $14.2 \mu \mathrm{M}$ (July 1999), respectively (table 1 ). Wind speeds $>3 \mathrm{~m} \mathrm{~s}^{-1}$ were recorded during monsoon months whereas lower wind speeds (1.76 to $2.1 \mathrm{~m} \mathrm{~s}^{-1}$ ) were recorded in the post-monsoon period (figure 2a). The high wind speed during monsoon coincided with lower surface salinity and vice-versa during the early premonsoon months. The surface temperature was lower in post-monsoon months when the study site experienced dry and cooler winds blowing from the land and greater during pre-monsoon months. The fresh water inputs in the study area during monsoon led to high nitrate levels which then declined sharply in the post-monsoon months followed by an increase during the pre-monsoon period.

\subsection{SPM, Chl a, C:N and bacterial abundance}

Both SPM and wind speed showed large scale seasonal variations which were also reflected in the distribution of $\mathrm{Chl} a$ in the surface waters (figure $2 \mathrm{a}$ and $\mathrm{b}$ ). Phytoplankton biomass was low during monsoon when the sampling site experienced higher wind speeds and greater suspended load. During other seasons, reduced suspended load, increased insolation and elevated nitrate concentrations supported the phytoplankton growth. Higher $\mathrm{Chl} a$ recorded during the month of September '98, November '98, April '99, September '99 and June 2000 coincided with low SPM.

The organic state of the particulate matter was assessed using the $\mathrm{C}: \mathrm{N}$ ratio $(\mathrm{w}: \mathrm{w})$ obtained from the POC and PON data. Higher ratios indicate accumulation of nitrogen poor organic matter (detritus, organic matter of terrestrial origin) whereas lower values indicate nitrogen rich organic matter derived from phytoplankton. The monthly C:N ratio (w:w) varied from 2.4 (October '99) to 18.8 (June '98) (figure 2b) and the average $\mathrm{C}: \mathrm{N}$ ratio was $9.5 \pm 3.5$ for the entire study period (table 1). A distinct seasonal variation was observed in the distribution of organic matter in the sampling site, which also reflected the changes in the phytoplankton biomass. The pre-monsoon and monsoon months generally had higher $\mathrm{C}: \mathrm{N}$ values whereas the post-monsoon months and the months having higher $\mathrm{Chl} a$ concentrations showed lower $\mathrm{C}: \mathrm{N}$ ratios.

The seasonal variation in total bacterial abundance (TBA) followed a trend similar to that of Chl $a$ concentrations. On an average, TBA was $2.56 \pm 2.42 \times 10^{6}$ cells ml ${ }^{-1}$ and varied from $0.59 \times 10^{6}$ (April 2000) to $10.21 \times 10^{6}$ cells ml $^{-1}$ (September '98) during the sampling period (figure 2c). During the enumeration, it was observed that the bulk of the bacterial population was attached to aggregates/particles of different origin. Morphologically, the bacteria were of varied shapes (long and short rods, spirals and cocci) and occurred either in chains, aggregate or scattered. From the figure, it is clear that TBA was higher during the post-monsoon months and in the months having greater phytoplankton biomass, low suspended load and changing organic matter composition.

\subsection{TEP concentrations}

The TEP concentrations expressed in terms of Xanthan gum equivalence ranged from 1.3 (July '99) to $149.1 \mathrm{mg}$ Xanthan gum eq. $\mathrm{m}^{-3}$ (June 2000) during the entire study period (figure 3a). 

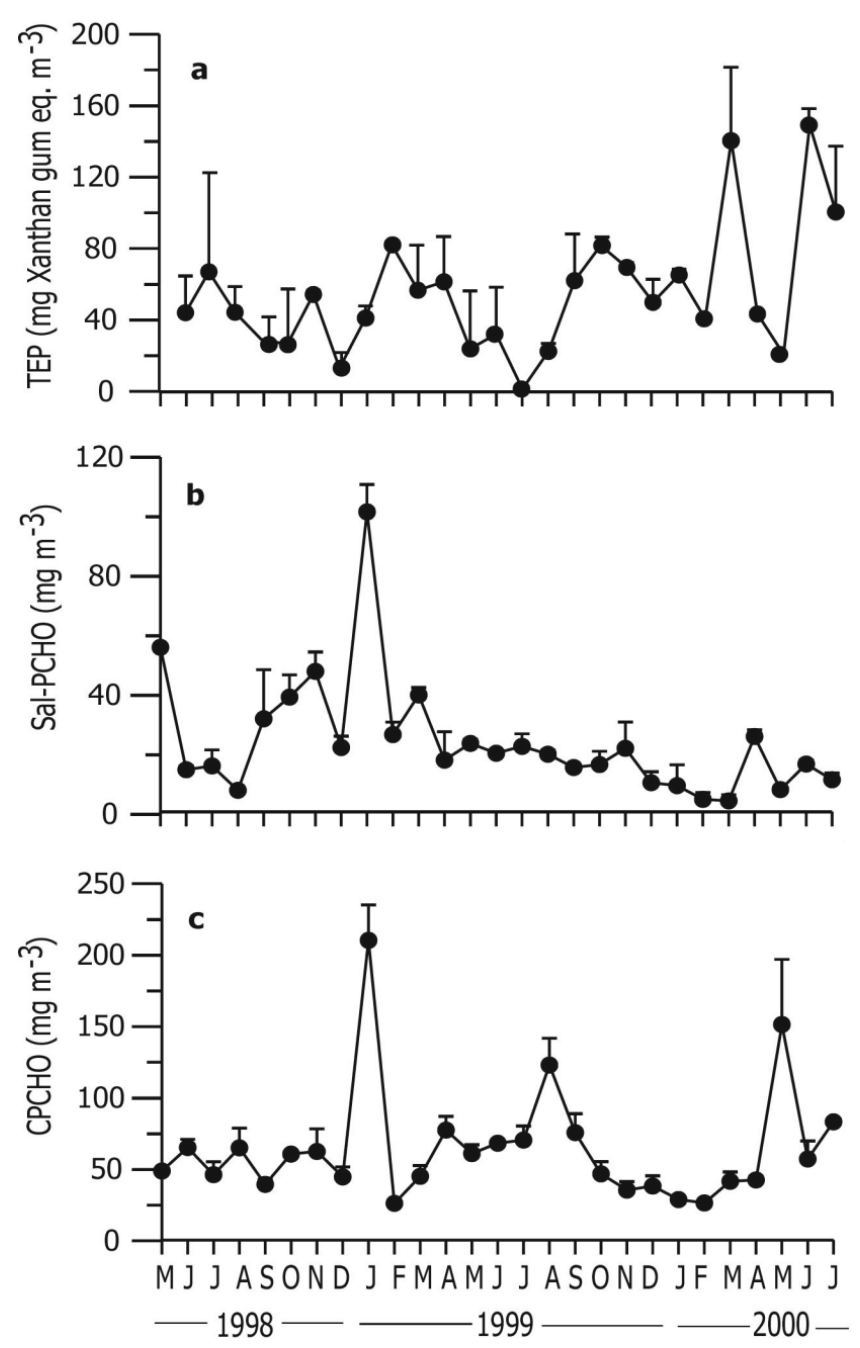

Figure 3. Seasonal distribution of (a) transparent exopolymer particles (TEP), (b) Sal-PCHO and (c) CPCHO in the surface waters of Dona Paula bay during 1998-2000.

Higher TEP values were recorded generally during monsoon months (July '98 and 2000) and in the months when phytoplankton biomass was relatively higher (November '98, April '99, October '99 and June 2000) during the study period. Except for the exceptionally low TEP concentrations in July 1999, generally TEP values ranged between 13 and $40 \mathrm{mg}$ Xanthan gum eq. $\mathrm{m}^{-3}$.

\subsection{Particle-associated carbohydrates (Sal-PCHO and $\mathrm{CPCHO}$ )}

The two forms of particle-associated carbohydrates, i.e., Sal-PCHO and CPCHO, showed a similar pattern of distribution in the surface water during the study period. The temporal variation of surface Sal-PCHO concentrations was more uniform compared to TEP concentrations, showed large scale variations (average: $24.3 \pm 19.9$; CV: $82 \%$ ) and were generally higher in the postmonsoon months when the study area experienced phytoplankton blooms (figure $3 \mathrm{~b}$ ). Overall, the Sal-PCHO concentrations varied from $4.5 \mathrm{mg} \mathrm{m}^{-3}$ (March 2000) to $101.6 \mathrm{mg} \mathrm{m}^{-3}$ (January '99) (table 1). Except for the unusually high value in January 1999, Sal-PCHO concentrations were always $<56 \mathrm{mg} \mathrm{m}^{-3}$.

In contrast, the $\mathrm{CPCHO}$ concentrations in the surface waters were generally higher than the Sal-PCHO concentrations. The mean CPCHO concentration for the entire period was $64.5 \pm$ $40.2 \mathrm{mg} \mathrm{m}^{-3}$ (CV: $62 \%$ ) (table 1), suggesting that unlike Sal-PCHO, CPCHO did not show large scale-variations. Overall, the $\mathrm{CPCHO}$ concentrations ranged from $26.2 \mathrm{mg} \mathrm{m}^{-3}$ (February '99) to $210.3 \mathrm{mg} \mathrm{m}^{-3}$ (January '99) over the study period (figure 3c). Interestingly, the high CPCHO concentrations during January '99 $\left(210.3 \mathrm{mg} \mathrm{m}^{-3}\right.$, April '99 (123.1 $\left.\mathrm{mg} \mathrm{m}^{-3}\right)$ and May $2000\left(151.4 \mathrm{mg} \mathrm{m}^{-3}\right)$ coincided with higher C:N values $(12.9,12.8$ and 11.3$)$, respectively.

\subsection{Phytoplankton, bacterial, TEP and carbohydrate-carbon}

The carbon contribution of the various particulate fractions is expressed as \% POC and is shown in table 1. The average \%Phyto-C, \%Bac-C, \% TEP-C, \%Sal-PCHO-C and \%CPCHO-C was $33.1 \pm 22.1 \%, 4.6 \pm 4.6 \%, 6.9 \pm 5.8 \%, 1.6 \pm 1.2 \%$ and $3.8 \pm 1.8 \%$, respectively.

\subsection{Statistical analyses}

Pearson's correlation coefficient for the entire study period was carried out to analyze the relationship of TEP and particle associated carbohydrates (both Sal-PCHO and CPCHO) with physical, nutrient and biological parameters (table 2). Except for the unusually high values of Sal-PCHO and CPCHO (January 1999), the entire data set was used for all the statistical analyses. TEP concentrations did not show any correlation with any other parameters except for a weak inverse correlation with TBA. CPCHO concentrations had significant correlation with SPM and poor relationship with phytoplankton biomass, and TBA. In contrast, Sal-PCHO values had significant positive correlation with TBA and an inverse trend with nitrate. Moreover, Chl $a$ showed a positive trend with Sal-PCHO and significant linear correlation with TBA $(r=0.543 ; p<0.001)$.

Principal component analysis (PCA) was carried out to delineate the parameters having similar seasonal behaviour. Factor loadings and eigen values were calculated for the various principal components extracted (table 3 ). The loadings were varimax normalized and the graph was plotted between 
Table 2. Pearson's correlation coefficient between various particulate parameters, bacterial abundance, wind speed, salinity and nitrate concentrations.

\begin{tabular}{lccccccccc}
\hline Parameters & Chlorophyll $a$ & C:N & TBA & Sal-PCHO & CPCHO & TEP & Wind & Salinity & Nitrate \\
\hline Suspended load & $-0.407^{*}$ & $0.488^{*}$ & -0.301 & -0.240 & $0.365^{*}$ & -0.096 & $0.72^{* * *}$ & -0.2205 & $0.677^{* * *}$ \\
Chlorophyll $a$ & & -0.259 & $0.543^{* * *}$ & 0.322 & 0.002 & -0.017 & $-0.395^{*}$ & -0.026 & $-0.513^{* *}$ \\
C:N & & & -0.338 & -0.203 & 0.253 & -0.181 & 0.331 & 0.051 & 0.336 \\
TBA & & & $0.586^{* * *}$ & -0.219 & $-0.368^{*}$ & -0.329 & -0.152 & -0.235 \\
Sal-PCHO & & & & & -0.136 & -0.267 & -0.16 & -0.235 & -0.36 \\
CPCHO & & & & & -0.229 & 0.222 & -0.332 & 0.023 \\
TEP & & & & & & 0.113 & 0.100 & -0.107 \\
\hline
\end{tabular}

$*: p<0.05 ;{ }^{* *}: p<0.01 ; * * *: p<0.001$.

Table 3. Factor loading and eigen values of various parameters extracted using principal component analysis.

\begin{tabular}{lrrr}
\hline Parameters & Factor 1 & Factor 2 & Factor 3 \\
\hline Suspended load & 0.794 & 0.058 & 0.396 \\
Chlorophyll $a$ & -0.589 & -0.427 & 0.007 \\
C:N & 0.309 & 0.286 & 0.586 \\
TBA & -0.302 & -0.781 & -0.146 \\
Sal-PCHO & -0.199 & -0.734 & -0.104 \\
CPCHO & 0.058 & 0.027 & 0.832 \\
TEP & 0.042 & 0.458 & -0.547 \\
Wind & 0.917 & 0.002 & 0.089 \\
Salinity & -0.327 & 0.584 & -0.159 \\
Nitrate & 0.878 & 0.116 & 0.014 \\
\hline Eigen values & 3.54 & 1.77 & 1.16 \\
\hline \% Variance explained & 29.33 & 19.8 & 15.64 \\
\hline
\end{tabular}

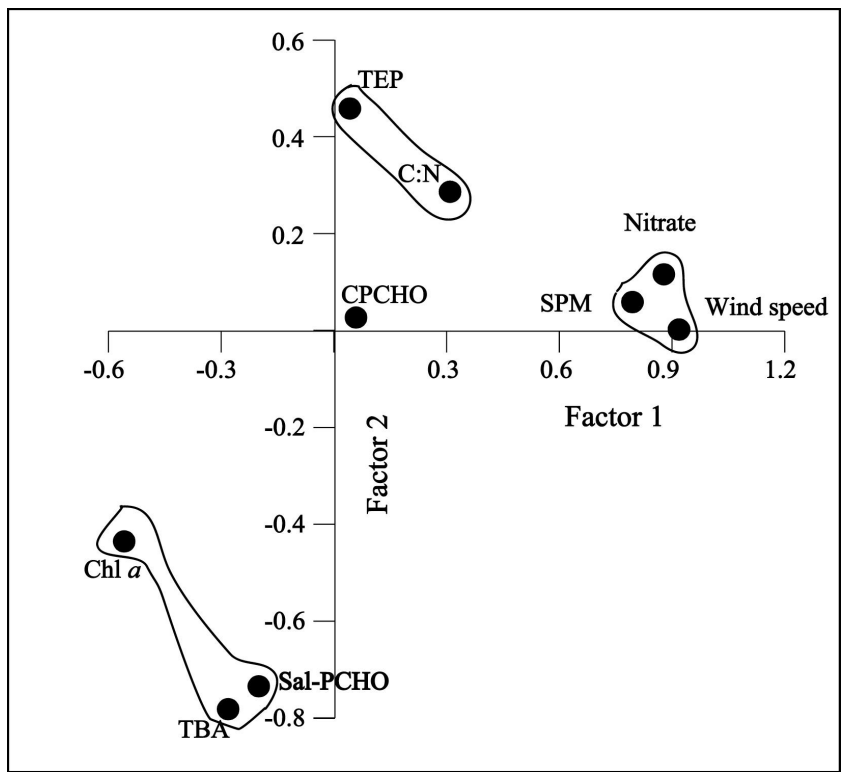

Figure 4. Varimax normalized PCA plot showing the grouping of factor loadings of different parameters collected from Dona Paula during 1998-2000.

factor 1 and factor 2 (figure 4). Factor 1 was representative of monsoon months when the wind speed, suspended load and nitrate concentrations were high. Factor 2 represents the months when phytoplankton biomass was high. The third factor had $\mathrm{CPCHO}$ and $\mathrm{C}: \mathrm{N}$ ratios as the dominant factors. On an X-Y plot, phytoplankton biomass, TBA and Sal-PCHO clustered in the same quadrant. Interestingly TEP was in a quadrant opposite to phytoplankton biomass (figure 4). From the figure and the factor loadings, it appeared that phytoplankton biomass, TBA and Sal-PCHO behaved in a similar fashion. On the other hand, suspended load and nitrate levels in the surface waters were controlled by wind speed and monsoonal activity.

In order to understand the inter-annual variations, the sampling period was split for the year 1998-99 (May '98 to June '99) and 1999-2000 (July '99 to July 2000) (table 1). From the table, it is clear that the period 1998-99 was more productive (higher Chl $a$ ) with greater bacterial biomass, particle-associated carbohydrate concentrations but lesser TEP concentrations. When the data was subjected to one-way ANOVA, significant interannual variations were observed only for Sal-PCHO $(F s=6.12 ; p<0.02)$, TBA $(F s=5.26 ; p<0.03)$ and $\operatorname{TEP}(F s=3.95 ; p<0.06)$ and phytoplankton biomass $(F s=2.94 ; p<0.09)$.

\section{Discussion}

\subsection{TEP and carbohydrate dynamics}

Coastal waters like bays and estuaries are highly dynamic and in a constant state of flux. Although water column characteristics change both diurnally and seasonally, the dynamics of TEP over a period of time is influenced by seasonal variations in the biotic and abiotic factors. The production and distribution of TEP is regulated by:

- biological factors (phytoplankton composition and age, exudate production, bacterial activity, grazing, etc.) (Alldredge et al 1993; Mari and Kiørboe 1996; Ling and Alldredge 2003),

- physical factors like turbulence (Zhou et al 1998; Stoderegger and Herndl 1999) and 
- nutrients like nitrate concentrations (Corzo et al 2000).

In the present study, the dynamics of TEP was not regulated by any single parameter. For example, changes in hydrodynamic conditions appeared to influence the TEP distribution. The monsoon months marked with greater wind speeds and higher suspended matter concentrations due to freshwater run-off and precipitation showed greater concentrations of TEP (figure 3a). Similarly, higher TEP concentrations in the months November '98, April '99, September '99 and June 2000 coincided with higher phytoplankton biomass. Nevertheless, both did not have any correlation with TEP concentrations. In a dynamic coastal environment, TEP production and removal/consumption are a continuous process which is influenced by various biological (phytoplankton community, grazing, heterotrophy, etc.) and abiotic (sortption to sediments, tidal flushing, land run-off, etc.) processes. These processes change seasonally as well as interannually. In this study, the months of monsoon and high phytoplankton biomass were the two major factors that regulated the water column characteristics (figure 4). On the contrary, significant interannual variations observed in TEP, TBA and Chl $a$ concentrations suggest that these parameters varied more compared to SPM and wind speed. Such inter-annual variability amongst key parameters regulating TEP and seasonal changes in the water column characteristics might explain the observed poor relationship of TEP with most parameters.

Another reason for the poor correlation between TEP and other parameters could be the resuspension of bottom sediments. Organic input due to resuspension in the study area could be $\sim 25 \%$ of the particulate organic carbon and is up to $45 \%$ in pre-monsoon months (Bhaskar et al 2000). In a shallow water coastal environment, resuspension of bottom sediments due to tidal currents or wave action redistributes sediment derived organic matter into the water column. Such events, therefore reintroduce TEP generated over a period into the water column. These TEP concentrations do not represent the actual sampling environments and therefore may not correlate with any of the parameters.

The probable sources of TEP in a coastal environment could not be clearly identified with the limited data-set. In the marine environment, extracellular organic matter derived from phytoplankton/bacteria serve as precursors for TEP (Passow and Alldredge 1994; Alldredge et al 1998; Stoderegger and Herndl 1999). In coastal waters, other sources like mucus nets of filter feeders (Herndl 1995), allochthonous sources, exudates of benthic microbial mats (Goto et al 1999) and macroalgal beds can also serve as sources of TEP (Ramaiah et al 2001). One such precursor for TEP is the large amount of extracellular carbohydrates (Sal-PCHO and CPCHO) produced by phytoplankton. Species belonging to Skeletonema, Chaetoceros, Nitzschia, Navicula and Coscinodiscus genera, many of which produce extracellular carbohydrates during their life-cycle (Hoagland et al 1993; Kiørboe and Hansen 1993), dominate the phytoplankton community in the months of September, November and April (Garg and Bhaskar 2000, personal observation). If Sal-PCHO and CPCHO were directly converted to TEP, then both should have a significant relationship with TEP concentrations. However, a poor correlation between TEP concentrations with $\mathrm{CPCHO}$ and a weak inverse trend with Sal-PCHO (table 2) suggests that these forms of carbohydrates were not the major source of TEP at the study site.

The role of TEP as an alternate carbon source for bacteria is debatable. For example, field studies by Passow and Alldredge (1994) and Mari and Kiørboe (1996) have shown a significant correlation between TEP abundance and bacterial abundance. Similarly, Kiorbøe and Hansen (1993) also found that bacterial cells were attached to TEP and suggested the probable role of TEP as carbon source to support the bacterial carbon demand. In contrast, Ramaiah et al (2000) did not find any clear correlation between bacterial biomass and TEP distribution in the Arabian Sea. In the present study, TBA in the surface waters of Dona Paula bay was similar to those reported from the offshore waters of the Arabian Sea and showed a weak inverse correlation with TEP. Our observations go well with the openocean observations of Ramaiah et al (2000) suggesting that bacteria might not be using TEP as an organic carbon source in these waters and may not have influenced the dynamics of TEP. Apart from bacteria, grazing by copepods and other filter feeders also play an important role in regulating TEP concentrations. However, this aspect of biological control of TEP was not addressed in this study.

Higher bacterial abundance observed during September, December and March coincided with higher phytoplankton biomass (figure $2 \mathrm{~b}$ ). Bacteria utilize a large fraction of organic matter produced during phytoplankton blooms to support their carbon demand. This was also reflected in the linear relationship of TBA with $\mathrm{Chl} a$ and Sal-PCHO (table 2). Interestingly, bacterioplankton had poor correlation with CPCHO. The differences in correlation of bacteria with the two carbohydrate fractions may be due to their properties. For example, Sal-PCHO are loosely attached polymers produced by phytoplankton, generally more labile and 
hence preferred by bacteria (Decho 1990). Alternately, $\mathrm{CPCHO}$ are cell-bound polymers, which have higher concentrations of acidic radicals and structural proteins and are found in microbial mats and cells that adhere to sediment (Stal 2003). In the present study, Sal-PCHO showed significant inter-annual variability compared to CPCHO. Moreover, Sal-PCHO had significant linear correlation with $\mathrm{Chl} a$, which suggests its phytoplankton origins. In contrast, CPCHO concentrations show a linear correlation with SPM (table 2), highlighting its association with sediments and therefore might be recalcitrant.

\subsection{Organic carbon pool}

The association of TEP and particle-associated carbohydrates with marine particles and their high $\mathrm{C}: \mathrm{N}$ ratios make them an important constituent of organic carbon pool in the marine environment (Passow et al 1994; Herndl 1995; Mari and Burd 1998; Kumar et al 1998). TEP-C estimations are not uniform, varying with the method employed for estimation and therefore its actual contribution is wide-ranging and debatable. A recent study on the TEP-C contribution estimated by its sizevolume ratio was as high as $80 \%$ of POC (Mari 1999). On the other hand, spectrophotometric estimation of TEP-C in the Bay of Biscay suggests that TEP-C can form up to $40 \%$ of the carbon reaching the sediment traps (Passow et al 2001). In the present study, the estimated TEP-C ranged from $0.12 \%$ (July '99) to $22.8 \%$ (February '99) of the POC whereas the average contribution was $6.88 \pm 5.81 \%$. Our estimates of TEP-C were significantly lower than those of Mari and Burd (1998) but still formed a significant fraction of the POC in the Dona Paula bay waters, second only to phytoplankton-carbon. Moreover, the poor correlation between TEP and microbial abundance suggests that these compounds may be refractory and therefore may not undergo immediate remineralization. Although the biogeochemical transformation of TEP-C in these waters is yet to be studied, it is possible that a significant fraction of POC might be escaping the microbial loop. The recalcitrant nature of TEP may have considerable effect on the quality of organic carbon in the study area. For example, the fate of particulate organic carbon has been studied to some extent in these waters (Bhaskar et al 2000). Assuming that the amount of TEP-C contributing to POC-flux is the same as in the surface waters, almost $7 \%\left(13.8 \mathrm{mg}_{-} \mathrm{C} \mathrm{m}^{-2} \mathrm{~d}^{-1}\right)$ of the sedimenting particulate organic carbon may not be degraded by bacteria but might be available to the benthic community. It is also possible that the sedimenting TEP-C may be grazed upon by zooplankton. In either scenario, the recalcitrant nature of TEP will lead to the depletion of labile organic carbon available in the water column. Also, TEP bound to aggregates may alter the quality of the organic matter reaching the sediments, thereby influencing the benthic population.

\section{Conclusion}

TEP derived carbon was the second most important source of carbon in the study area after phytoplankton biomass carbon, and highlights its significance in coastal waters. However, no clear relationship could be established between TEP concentration and other parameters in this study. Inter-annual variability and seasonal influences on hydrodynamic conditions may play an important role in the distribution of TEP and Sal-PCHO in coastal waters. Sal-PCHO and CPCHO appear to be two distinct forms of carbohydrates with distinct inter-annual and seasonal variability. Bacteria may be using Sal-PCHO to meet its carbon demand. Further studies are required to address the role of TEP as a carbon sink and its turnover in these waters.

\section{Acknowledgements}

The authors would like to thank Dr E Desa, Director, National Institute of Oceanography, Goa for his support and encouragement. This work was a part of the doctoral work of PVB. PVB also acknowledges CSIR-New Delhi for providing a fellowship during this research.

\section{References}

Alldredge A L, Passow U and Logan B E 1993 The abundance and significance of a class of transparent organic particles in the ocean; Deep-Sea Res. I 40 1131-1140.

Alldredge A L, Passow U and Haddock S H D 1998 The characteristics and transparent exopolymer particles (TEP) content of marine snow formed from thecate dinoflagellates; J. Plank. Res. 20 393-406.

Banse K 1977 Determining the carbon to chlorophyll $a$ of natural phytoplankton; Mar. Biol. 41 199-212.

Bhaskar P V and Bhosle N B 2004 Microbial extracellular polysaccharides and their role in marine biogeochemical processes; Curr. Sci. 88 45-53.

Bhaskar P V, Cardozo E, Giriyan A, Garg A and Bhosle N B 2000 Sedimentation of particulate matter in the Dona Paula Bay; west coast of India during November to May 1995-1997; Estuaries 23 722-734.

Bhosle N B, Sawant S S, Garg A and Wagh A B 1995 Isolation and partial chemical analysis of exopolysaccharides from the marine fouling diatom Navicula subinflata; Bot. Mar. 38 103-110.

Bhosle N B, Bhaskar P V and Ramachandran S 1998 Abundance of dissolved polysaccharides in the oxygen minimum layer of the northern Indian Ocean; Mar. Chem. 63 171-182. 
Chin W-C, Orellana M V and Verdugo P 1998 Spontaneous assembly of marine dissolved organic matter into polymeric gels; Nature 391 568-572.

Corzo A, Morillo J A and Rodriguez S 2000 Production of transparent exopolymer particles (TEP) in cultures of Chaetoceros calcitrans under nitrogen limitation; Aquat. Microb. Ecol. 23 63-72.

Dam H G and Drapeau D T 1995 Coagulation efficiency, organic matter glues and the dynamics of particles during a phytoplankton bloom in a mesocosm study; Deep-Sea Res. II 42 111-124.

Decho A W 1990 Microbial exopolymer secretion in ocean environments: their role in food webs and marine processes; Oceanogr. Mar. Biol. Annu. Rev. 28 73-153.

Decho A W 2000 Microbial biofilms in intertidal systems: an overview; Cont. Shelf Res. 20 1257-1273.

Devassy V P and Goes J I 1988 Phytoplankton community structure in a tropical estuarine complex (central west coast of India); Estuarine Coast. Shelf Sci. 27 671-685.

Dubois M K, Gilles K A, Hamilton J K, Rebers P A and Smith F 1956 A colorimetric method for the determination of sugar and related substances; Anal. Chem. 28 $350-356$.

Engel A 2004 Distribution of transparent exopolymer particles (TEP) in the northeast Atlantic Ocean and their potential significance for aggregation processes; Deep-Sea Res. I 51 83-92.

Engel A and Passow U 2001 Carbon and nitrogen content of transparent exopolymer particles (TEP) in relation to their Alcian Blue adsorption; Mar. Ecol. Progr. Ser. 219 $1-10$.

Engel A, Meyerhofer M and von Brockel K 2002 Chemical and biologcal composition of suspended particles and aggregates in the Baltic Sea in Summer (1999); Estuarine Coast. Shelf Sci. 55 729-741.

Garg A and Bhaskar P V 2000 Fluxes of diatoms in the Dona Paula bay, west coast of India; J. Plankton Res. 22 2125-2136.

Garrison D L, Gowing M M, Hughes M P, Campbell C, Caron D A, Denett M R, Shalapyonok A, Olson R J, Landry M R, Brown S L, Lin H P, Azam F, Steward G F, Ducklow H W and Smith D C 2000 Microbial food web structure in the Arabian Sea: A US JGOFS study; DeepSea Res. II 47 1387-1422.

Goto N, Kawamura T, Mitamura O and Terai H 1999 Importance of extracellular organic carbon production in the total primary production by tidal-flat diatoms in comparison to phytoplankton; Mar. Ecol. Progr. Ser. 190 $289-295$.

Herndl G J 1995 Microbial dynamics in marine aggregates; In: Seasonal dynamics of planktonic ecosystems and sedimentation in coastal waters (eds) Floderus S, Heiskanen A S, Olesen M and Wassmann P, Symposium Proceedings, NurmiPrint Oy., pp. 81-105.

Hoagland K, Rosowski J R, Gretz M R and Roemer S C 1993 Diatom extracellular polymeric substances: Function, fine structure, chemistry and physiology; J. Phycol. 29 $537-566$.

Hung C-C, Tang D, Warnken K W and Santschi P H 2001 Distributions of carbohydrates, including uronic acids, in estuarine waters of Galveston bay; Mar. Chem. 73 305-318.

Kaltenbock E and Herndl G J 1992 Ecology of amorphous aggregations (marine snow) in the northern Adriatic Sea: IV Dissolved nutrients and the autotrophic community associated with marine snow; Mar. Ecol. Progr. Ser. $\mathbf{8 7}$ $147-159$

Kiørboe T and Hansen J L S 1993 Phytoplankton aggregate formation: Observations of patterns and mechanisms of cell sticking and the significance of exopolymeric material; J. Plankton Res. 15 993-1018.

Kiørboe T, Lundsgaard C, Olesen M and Hansen J L S 1994 Aggregation and sedimentation during a spring phytoplankton bloom: A field experiment to test the coagulation theory; J. Mar. Res. 52 297-323.

Kumar M D, Sarma V V S S, Ramaiah N, Gauns M and de Sousa S N 1998 Biogeochemical significance of transparent exopolymer particles (TEP) in the Indian Ocean; Geophys. Res. Lett. 25 81-84.

Ling S C and Alldredge A L 2003 Does the marine copepod Calanus pacificus consume transparent exopolymer particles (TEP)?; J. Plankton Res. 25 507-515.

Mari X 1999 Carbon content and C:N ratio of transparent exopolymeric particles (TEP) produced by bubbling exudates of diatoms; Mar. Ecol. Progr. Ser. 183 59-71.

Mari X and Burd A 1998 Seasonal size spectra of transparent exopolymeric particles (TEP) in a coastal sea and comparison with those predicted using coagulation theory; Mar. Ecol. Progr. Ser. 163 63-76.

Mari X and Kiørboe T 1996 Abundance, size distribution and bacterial colonization of transparent exopolymeric particles (TEP) during spring in Kattegat; J. Plankton Res. 18 969-986.

McKee M P, Ward J E, Milke L M and MacDonald B A 2000 Release of mucopolysaccharides by bivalved molluscs and their contribution to the production of transparent exopolymer particles (TEP) in near shore waters; J. Shellfish Res. 19664.

Myklestad S M, Holm-Hansen O, Varum K M and Volcani B E 1989 Rate of release of extracellular amino acids and carbohydrates from the marine diatom Chaetoceros affinis; J. Plankton Res. 11 763-773.

Pakulski J D and Benner R 1994 Abundance and distribution of carbohydrates in the ocean; Limnol. Oceanogr. 39 930-940.

Parsons T, Maita Y and Lalli C M 1984 A manual of chemical and biological methods for seawater analysis (Oxford: Pergamon Press).

Passow U 2002 Transparent exopolymer particles (TEP) in aquatic environments; Progr. Oceanogr. 55 287-333.

Passow U and Alldredge A L 1994 Distribution, size and bacterial colonization of transparent exopolymeric particles (TEP) in the ocean; Mar. Ecol. Progr. Ser. 113 185-198.

Passow U and Alldredge A L 1995a Aggregation of a diatom bloom in a mesocosm: The role of transparent exopolymer particles (TEP); Deep-Sea Res. II 42 99-110.

Passow U and Alldredge A L 1995b A dye-binding assay for the spectrophotmetric measurement of transparent exopolymer particles (TEP); Limnol. Oceanogr. 40 1326-1335.

Passow U, Alldredge A L and Logan B E 1994 The role of particulate carbohydrate exudates in the flocculation of diatom blooms; Limnol. Oceanogr. 41 335-357.

Passow U, Shipe R F, Murray A, Pak D K, Brzezinski M A and Alldredge A L 2001 The origin of transparent exopolymer particles (TEP) and their role in sedimentation of particulate matter; Cont. Shelf Res. 21 327-346.

Raimbault P and Gerd 1991 A semi-automatic wet oxidation method for the determination of particulate organic nitrogen collected on filters; Limnol. Oceanogr. 36 405-408.

Ramaiah N, Yoshikawa T and Furuya K 2001 Temporal variations in transparent exopolymer particles (TEP) associated with a diatom spring bloom in a subarctic ria in Japan; Mar. Ecol. Progr. Ser. 212 79-88.

Ramaiah N, Sarma V V S S, Gauns M, Kumar D M and Madhupratap M 2000 Abundance and relationship 
of bacteria with transparent exopolymer particles during the 1996 summer monsoon in the Arabian Sea; Proc. Indian Acad. Sci. (Earth Planet. Sci.) 109 $1-9$.

Romankevich E A 1984 Geochemistry of organic matter in the ocean (Berlin: Springer-Verlag) (FRG) $351 \mathrm{pp.}$

Stal L J 2003 Microphytobenthos, their extracellular polymeric substances, and the morphogenesis of intertidal sediments; Geomicrobiol. J. 20 463-478.

Schuster S and Herndl G J 1995 Formation and significance of transparent exopolymeric particles in the northern Adriatic Sea; Mar. Ecol. Progr. Ser. 124 $227-236$.

Stoderegger K and Herndl G J 1999 Production of exopolymer particles by marine bacterioplankton under contrasting turbulence conditions; Mar. Ecol. Progr. Ser. 189 9-16.

Strickland J D H and Parsons T 1975 A manual of sea-water analysis; Fisheries Res. Board Can., Bulletin no. 125.

Thornton D 2004 Formation of transparent exopolymer particles (TEP) from macroalgal detritus; Mar. Ecol. Progr. Ser. 282 1-12.

Underwood G J C, Paterson D M and Parkes R J 1995 The measurement of microbial carbohydrate exopolymers from intertidal sediments; Limnol. Oceanogr. 40 $1243-1253$.

Zhou J, Mopper K and Passow U 1998 The role of surfaceactive carbohydrates in the formation of transparent exopolymer particles by bubble adsorption of seawater; Limnol. Oceanogr. 43 1860-1871. 